Article

\title{
Sub-Pilot-Scale Autocatalytic Pyrolysis of Wastewater Biosolids for Enhanced Energy Recovery
}

\author{
Zhongzhe Liu ${ }^{1}$, Simcha Singer ${ }^{2}$, Daniel Zitomer ${ }^{1}$ and Patrick McNamara ${ }^{1, *(1)}$ \\ 1 Department of Civil, Construction and Environmental Engineering, Marquette University, \\ Milwaukee, WI 53233, USA; zhongzhe.liu@marquette.edu (Z.L.); daniel.zitomer@marquette.edu (D.Z.) \\ 2 Department of Mechanical Engineering, Marquette University, Milwaukee, WI 53233, USA; \\ simcha.singer@marquette.edu \\ * Correspondence: patrick.mcnamara@marquette.edu; Tel.: +1-414-288-2188
}

Received: 30 September 2018; Accepted: 5 November 2018; Published: 7 November 2018

check for updates

\begin{abstract}
Improving onsite energy generation and recovering value-added products are common goals for sustainable used water reclamation. A new process called autocatalytic pyrolysis was developed at bench scale in our previous work by using biochar produced from the biosolids pyrolysis process itself as the catalyst to enhance energy recovery from wastewater biosolids. The large-scale investigation of this process was used to increase the technical readiness level. A sub-pilot-scale catalytic pyrolytic system was constructed for this scaled-up study. The effects of configuration changes in both pyrolytic and catalytic reactors were investigated as well as the effect of vapor-catalyst contact types (i.e., downstream, in-situ) on product yield and quality. The sub-pilot-scale test with downstream catalysis resulted in higher py-gas yields and lower bio-oil yields when compared to results from a previous batch, bench-scale process. In particular, the py-gas yields increased 2.5 -fold and the energy contained in the py-gas approximately quadrupled compared to the control test without autocatalysis. Biochar addition to the feed biosolids before pyrolysis (in-situ catalysis) resulted in increased py-gas production, but the increase was limited. It was expected that using a higher input pyrolyzer with a better mixing condition would further improve the py-gas yield.
\end{abstract}

Keywords: wastewater sludge; bio-oil; tar cracking; py-gas; biochar; auger reactor; catalyst; in-situ catalysis; downstream catalysis

\section{Introduction}

Water resource recovery facilities (WRRFs) are currently facing many challenges including increased energy generation, nutrient recovery and pollutant removal [1-4]. Sustainable WRRFs need to produce more onsite energy generation and recover more value-added products. Wastewater biosolids (i.e., treated wastewater sludge) are a major byproduct of WRRFs, and over 8 million dry tons are produced in the United States every year, of which 55\% are land applied due to their beneficial soil conditioner properties [5]. For example, heat dried biosolids (Milorganite ${ }^{\circledR}$ ) produced by Milwaukee Metropolitan Sewerage District (MMSD) are an established soil conditioner. Over 45,000 tons of Milorganite ${ }^{\circledR}$ are produced annually and are applied to golf courses, turf farms and home lawns. Biosolids are treated using processes such as anaerobic digestion, but their residual energy is refractory and is not fully recovered before biosolids land application [6]. Additionally, organic contaminants of emerging concern in biosolids such as triclosan are potential issues as well [7-11]. Hence, post-treatment techniques to improve energy and resource recovery and reduce adverse environmental impacts are crucial to achieving sustainable WRRFs.

Thermochemical processing of biosolids is an acknowledged technology for energy and resource recovery, such as incineration, gasification, and pyrolysis [12-17]. Pyrolysis is considered a 
promising low-waste solution to biosolids handling in terms of energy recovery, resource recovery, and contaminant removal [18]. Pyrolysis is a process that decomposes carbonaceous materials (e.g., biosolids) upon heating in an oxygen deficient or free environment. The resulting products are biochar, pyrolysis gas (py-gas), and pyrolysis condensate (bio-oil or py-oil) that may contain multiple aqueous and nonaqueous phases. Biochar is usually used as a precursor for activated carbon production or as a valuable soil amendment, which improves plant growth. Py-gas and the nonaqueous phase of bio-oil can both be used as fuels after conditioning. Additionally, biosolids pyrolysis removes recalcitrant contaminants including triclosan and triclocarban, antibiotic resistance genes, as well as reduces total estrogenicity of the resulting biochar [19-21]. However, bio-oil from conventional slow pyrolysis of biosolids (biochar is the target product with heating rate below $100{ }^{\circ} \mathrm{C} / \mathrm{min}$, hereafter referred to as pyrolysis) normally accounts for at least $40 \%$ of the total product mass [17] and requires costly pretreatment due to its corrosive and unstable properties before it can be used as a clean fuel [22]. In contrast, py-gas can be more easily burned in gas engines for energy recovery. Therefore, cost-efficient catalyst is of great interest to reduce bio-oil yield and increase py-gas yield during biosolids pyrolysis.

A new process called autocatalytic pyrolysis was developed in our previous batch, bench-scale work by using biosolids biochar from the process itself as the catalyst to enhance energy recovery from biosolids (Figure S1) [23]. The energy analysis also showed that the new process can be energy neutral by partially using py-gas energy [24]. In the autocatalytic pyrolysis process, the dried biosolids is pyrolyzed in the pyrolytic reactor to generate biosolids biochar and pyrolysis vapor (py-gas and uncondensed bio-oil). The biochar is immediately conveyed to the downstream reactor as the catalyst (or mixed with the dried biosolids at the feeding end). Both py-gas and bio-oil are upgraded via autocatalysis to produce high yield py-gas and low yield bio-oil condensate because biosolids biochar contains high calcium and iron contents [23]. The spent biochar is still considered as an activated carbon precursor or a soil amendment. The bench-scale study showed that biosolids biochar increased the py-gas yield by nearly 2 -fold. The catalyzed bio-oil contained fewer hydrocarbon constituents. The energy shifted from bio-oil to py-gas, indicating the potential for easier on-site energy recovery using the relatively clean py-gas $[23,25]$.

In the development of a new process, after the concept is validated in a laboratory environment, a prototype demonstration such as a sub-pilot scale test is needed to increase the technical readiness level. Some biosolids pyrolysis technologies have been evaluated at a large scale. Chang et al. (2016) studied the effectiveness of sewage sludge pyrolysis using pilot-scale pyrolysis systems to promote the engineering application of municipal sludge pyrolysis technology [26]. They found that the optimal operating conditions and product characteristics were in accordance with those of the bench experiment. Lin et al. (2012) scaled up a microwave-heating process to develop the industrial application of sludge-based adsorbents with bio-oil production $[27,28]$. In addition, sludge was pyrolyzed in a pilot plant with manure to evaluate the performance of synergistic treatment [29]. As for large-scale catalytic pyrolysis, commercial hydroprocessing catalyst and ZSM- 5 catalyst have been investigated to produce infrastructure-compatible biofuels and petrochemical intermediates from biomass (e.g., sugarcane bagasse and pinewood) at a pilot-scale [30,31]. However, catalytic biosolids pyrolysis has been rarely studied at large scale. Because of the good performance of the bench-scale autocatalytic biosolids pyrolysis, a scaled-up study (i.e., sub-pilot scale) was needed.

The overarching goal of this study was to evaluate the large-scale autocatalytic performance during biosolids pyrolysis using a continuous pyrolytic system. The effect of the configuration changes in both pyrolytic and catalytic reactors as well as the effect of vapor-catalyst contact types (i.e., downstream, in-situ) on the product yield and quality were investigated. This research was conducted to determine whether biosolids biochar catalyst (BBC) particles can be directly added to the reactor for in-situ catalysis or whether a downstream catalytic reactor (i.e., downstream catalysis) is required. Our sub-pilot-scale test revealed that the downstream catalysis had better catalytic performance with higher py-gas yield and lower bio-oil yield when compared to the previous 
bench-scale results. Furthermore, in-situ catalysis resulted in increased py-gas production, but the increase was limited. It was expected that using a higher input pyrolyzer with a better mixing condition would further improve the py-gas yield.

\section{Results and Discussion}

\subsection{Validation of the Sub-Pilot-Scale Pyrolysis System}

The newly constructed sub-pilot-scale pyrolytic system required a validation test in comparison with the bench-scale test. All the units of the system functioned well during the validation test and the sub-pilot-scale results were in accordance with the bench-scale results (Figure S2). The biochar mass fraction was approximately $50 \%$ for both scales. The bio-oil and py-gas yields were similar, which were approximately $35 \%$ and $15 \%$, respectively. In addition, the biochar products look similar by appearance. As for the bio-oil optical property, both condensates contained a light non-aqueous phase and an aqueous phase that contained water and soluble organics, indicating that the condensation performance was acceptable. Hence, the system was qualified for the following sub-pilot-scale research.

\subsection{Product Yields and Properties}

The downstream catalysis process greatly increased the py-gas yield while the in-situ catalysis process only slightly increased the py-gas yield (Figure 1). For the downstream catalysis process, the increase of catalyst to biosolids mass ratio resulted in a higher py-gas yield and lower bio-oil yield. In particular, at $800^{\circ} \mathrm{C}$ with a catalyst to biosolids mass ratio of 1 , the mass fraction of bio-oil decreased from $36 \%$ to $4 \%$ of all products by mass. Meanwhile, the py-gas yield increased by 2.5 -fold (from $23 \%$ to $57 \%$ ). When compared with the bench-scale autocatalytic results, the py-gas yield was much higher and the bio-oil yield was much lower. With a catalyst to biosolids mass ratio of 1, the bio-oil yield was below $5 \%$ for the sub-pilot-scale test while the bio-oil yield was $20 \%$ for the bench-scale test [23]. The excellent sub-pilot-scale autocatalytic effect with downstream catalysis was most likely due to the enlarged size of the downstream catalyst bed $(7 \mathrm{~cm}$ inner diameter and $30 \mathrm{~cm}$ long for sub-pilot-scale versus $0.79 \mathrm{~cm}$ inner diameter and $27.9 \mathrm{~cm}$ long for bench-scale), which provided more surface area and longer inside retention time to improve the pyrolysis vapor decomposition and upgrading.

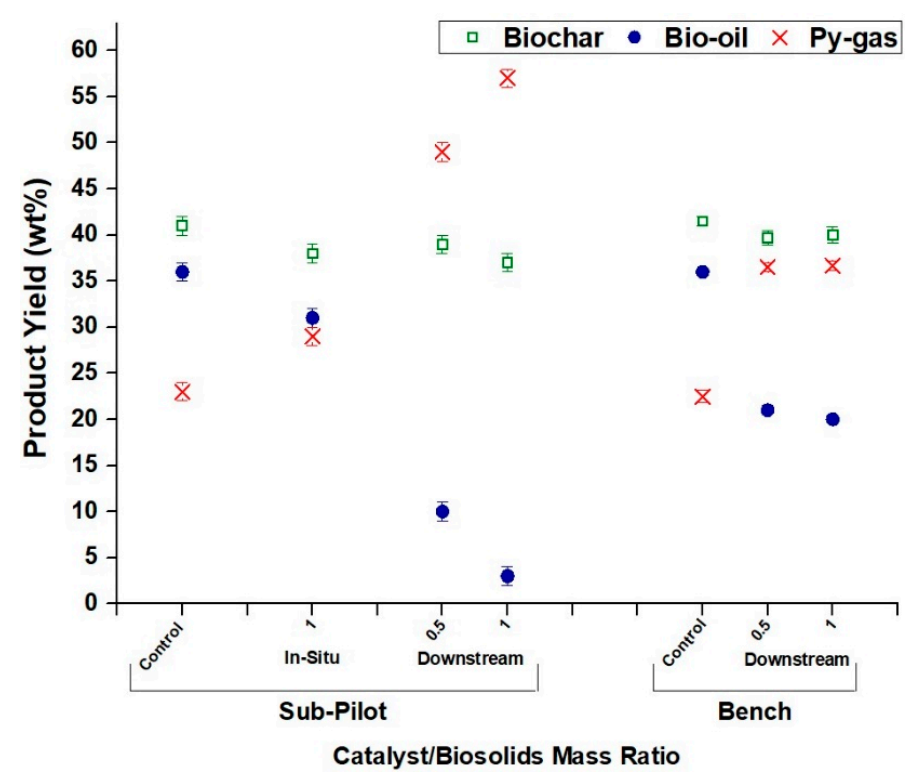

Figure 1. Product mass fractions of biosolids pyrolysis ("control" denotes the $800{ }^{\circ} \mathrm{C}$ non-catalytic test with the downstream temperature of $500{ }^{\circ} \mathrm{C}$; " $0.5^{\prime \prime}$ and " 1 " indicate the $800{ }^{\circ} \mathrm{C}$ autocatalytic tests performed with a catalyst/biosolids mass ratio of 0.5 and 1 , respectively; the bench-scale results were from our previous study [23]). 
For the in-situ catalysis, the py-gas mass fraction increased $6 \%$ (from $23 \%$ to $29 \%$ ), while the bio-oil yield decreased 5\% (from 36\% to $31 \%$ ). The limited autocatalytic effect was possibly due to the low feeding rate that was restricted by the design of the feeding section. The low feeding rate resulted in low capacity occupancy with poor contact between BBC and pyrolysis vapor (e.g., vapor is light on the top while BBC is heavy at the bottom). If the feeding rate can be increased with more BBC in the pyrolysis reactor, the improvement from the autocatalytic effect could be expected. Since the sub-pilot-scale downstream catalysis performed much better in comparison with in-situ catalysis in this study, only the py-gas and bio-oil from downstream catalysis process were analyzed for investigating the changes in properties and energy yields.

The py-gas of the sub-pilot-scale downstream autocatalytic tests (Figure 2) had higher $\mathrm{H}_{2}$ concentration and lower $\mathrm{CO}_{2}$ concentration compared to those of the control test. $\mathrm{H}_{2}$ increased from $26 \%$ (control) to above $40 \%$ while $\mathrm{CO}_{2}$ decreased from $25 \%$ (control) to below $10 \%$. The $\mathrm{H}_{2} \%$ increase was possibly a result of multiple thermochemical reactions such as steam methane reforming $\left(\mathrm{H}_{2} \mathrm{O}+\mathrm{CH}_{4} \leftrightarrows 3 \mathrm{H}_{2}+\mathrm{CO} ; 2 \mathrm{H}_{2} \mathrm{O}+\mathrm{CH}_{4} \leftrightarrows 4 \mathrm{H}_{2}+\mathrm{CO}_{2}\right)$, dry reforming $\left(\mathrm{CO}_{2}+\mathrm{CH}_{4} \leftrightarrows 2 \mathrm{CO}+2 \mathrm{H}_{2}\right)$, or the water gas shift reaction $\left(\mathrm{CO}+\mathrm{H}_{2} \mathrm{O} \leftrightarrows \mathrm{CO}_{2}+\mathrm{H}_{2}\right)$. In addition, bio-oil decomposition and reforming (e.g., Tar $+\mathrm{H}_{2} \mathrm{O} \rightarrow \mathrm{CO}, \mathrm{CO}_{2}$, and $\mathrm{H}_{2}$ ) also contributed to the $\mathrm{H}_{2} \%$ increase [23]. The decrease in $\mathrm{CO}_{2} \%$ could be a result of the biochar-enhanced dry reforming and the relative increase of other gas components [32,33]. $\mathrm{CO} \%$ and $\mathrm{CH}_{4} \%$ decreased slightly during the sub-pilot-scale downstream autocatalytic tests. Even though the concentration of each gas component was different between the sub-pilot-scale and the bench-scale tests, the trend during autocatalysis was very similar.

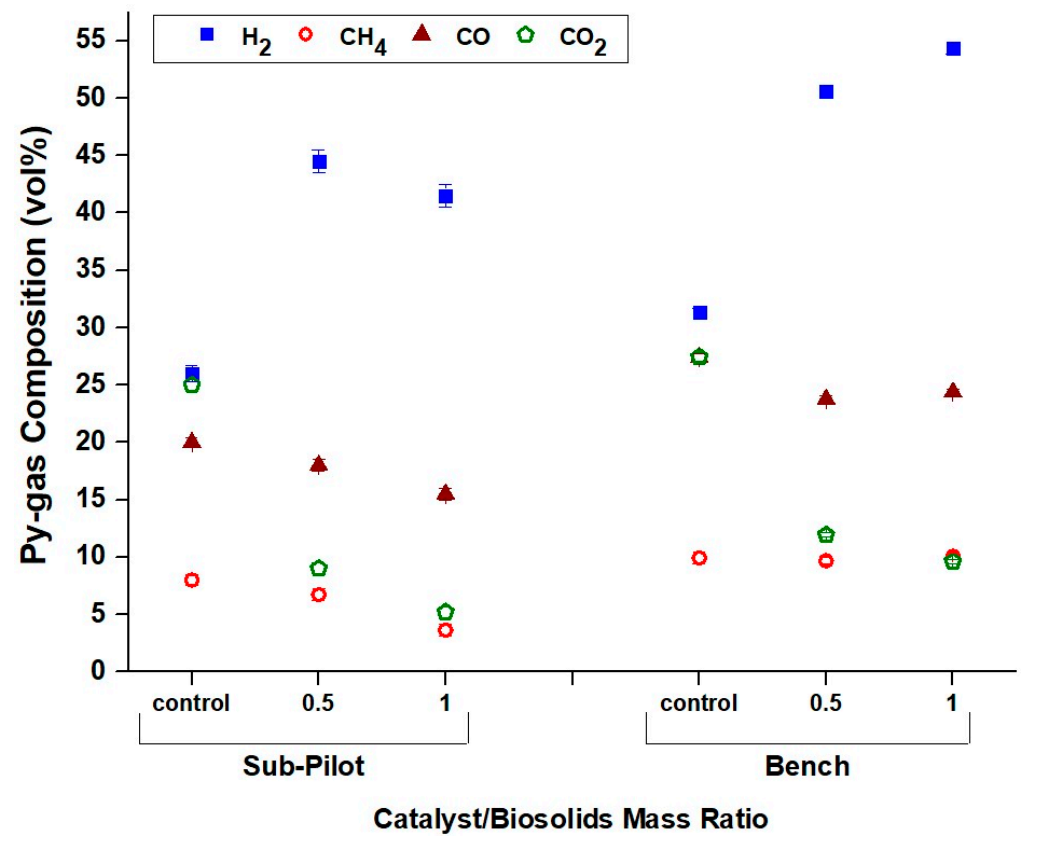

Figure 2. Py-gas composition of biosolids pyrolysis ("control" denotes the $800{ }^{\circ} \mathrm{C}$ non-catalytic test with the downstream temperature of $500{ }^{\circ} \mathrm{C} ;$ “ $0.5^{\prime \prime}$ and " 1 " indicate the $800{ }^{\circ} \mathrm{C}$ downstream autocatalytic tests performed with a catalyst/biosolids mass ratio of 0.5 and 1, respectively; the bench-scale results were from our previous study [23]).

The sub-pilot-scale downstream autocatalysis process changed the bio-oil chemical composition (Figure 3). According to gas chromatography-mass spectroscopy (GC-MS) analysis, the $800{ }^{\circ} \mathrm{C}$ autocatalytic bio-oil contained very few detectable hydrocarbons. Only toluene, pyridine, and ethylbenzene had identifiable peaks. In contrast, many hydrocarbon peaks in the control bio-oil were detected by GC-MS such as toluene, pyridine, ethylbenzene, styrene, phenol, cresol, indole, and cuscohygrine.

In addition, the color of the catalyzed bio-oil became clearer with higher catalyst to biosolids mass ratio (Figure S3b). The control bio-oil contained a thick dark and lighter-phase fraction (mainly 
unsaturated hydrocarbons) (Figure S3a). Due to the higher viscosity of the thick dark phase, the bottom aqueous phase (light brown layer) dripped out from the condensing system first (i.e., the left two containers in Figure S3a mostly contained the aqueous phase). Compared to the control test, the mass of dark and lighter-phase fraction was greatly reduced via autocatalysis. The test with catalyst to biosolids mass ratio of 0.5 contained a very thin light layer and the test with catalyst to biosolids mass ratio of 1 only had the aqueous phase (Figure S3b). In particular, the optical property of catalyzed bio-oil droplet was almost transparent with catalyst to biosolids mass ratio of 1 (Figure S3c). Dark bio-oil color indicated the presence of unsaturated hydrocarbons [34]. Hence, the autocatalysis produced a cleaner bio-oil product with fewer unsaturated hydrocarbons, which could be beneficial for subsequent upgrading or disposal.

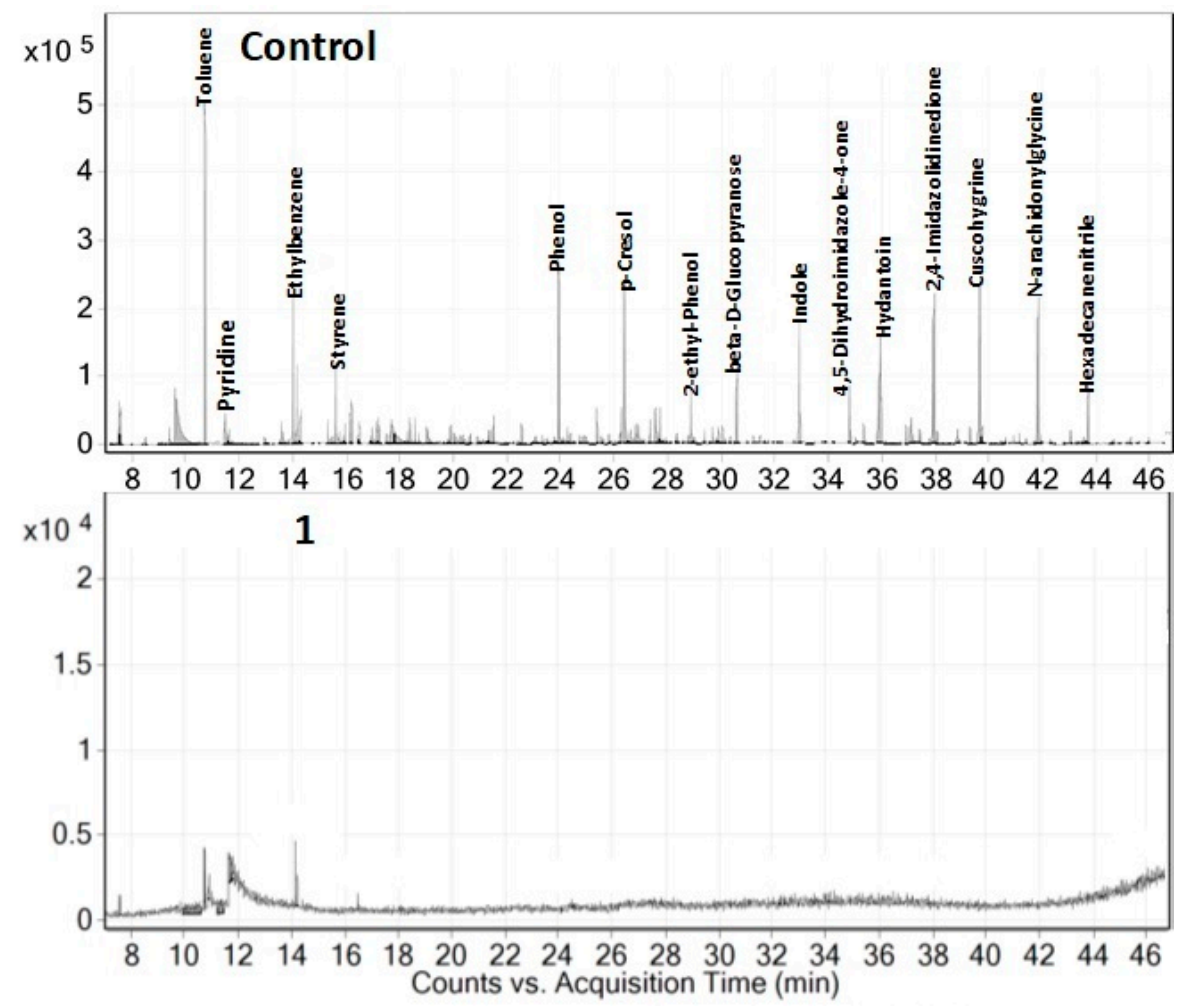

Figure 3. GC-MS of bio-oils from the sub-pilot-scale tests ("control" denotes the $800{ }^{\circ} \mathrm{C}$ non-catalytic test with the downstream temperature of $500{ }^{\circ} \mathrm{C} ; " 11^{\prime}$ indicates the $800{ }^{\circ} \mathrm{C}$ downstream autocatalytic test performed with a catalyst/biosolids mass ratio of 1 ).

\subsection{Product Energy Yields}

Similar to the bench-scale results, the sub-pilot-scale catalyzed bio-oil higher heating value (HHV) decreased from $8000 \mathrm{~kJ} / \mathrm{kg}$-bio-oil (control test) to around $2000 \mathrm{~kJ} / \mathrm{kg}$-bio-oil with the catalyst to biosolids mass ratio of 0.5 or 1 (Figure S4). The HHV decrease was possibly because of the decrease in organic constituents described above and the formation of water during catalysis [35]. The sub-pilot-scale catalyzed py-gas HHV increased slightly with the catalyst to biosolids mass ratio of 0.5 while decreased by $3000 \mathrm{~kJ} / \mathrm{m}^{3}$ with the catalyst to biosolids mass ratio of 1 (Figure S4). The decrease was because less $\mathrm{CH}_{4}$ and $\mathrm{CO}$ was produced (Figure 2). As for biochar, the energy content for bench and sub-pilot scales was similar, which was approximately $1,1650 \mathrm{~kJ} / \mathrm{kg}$.

The sub-pilot-scale downstream autocatalysis process increased py-gas energy yield and decreased bio-oil energy yield (Figure 4). In particular, py-gas energy yield increased as the catalyst to biosolids mass ratio increased. For example, with the catalyst to biosolids mass ratio of 1 , the py-gas energy increased to $10,000 \mathrm{~kJ} / \mathrm{kg}$-biosolids-pyrolyzed from the $2760 \mathrm{~kJ} / \mathrm{kg}$ of the control test. In the meantime, due to the greatly reduced yield and energy content in bio-oil, the bio-oil energy decreased 
from $3000 \mathrm{~kJ} / \mathrm{kg}$-biosolids-pyrolyzed to below $100 \mathrm{~kJ} / \mathrm{kg}$. The energies in non-catalyzed bio-oil and py-gas were almost equal (control test), but the energy shifted greatly from bio-oil to py-gas energy via autocatalysis. As aforementioned, py-gas is easier and cleaner for on-site energy recovery compared to bio-oil.

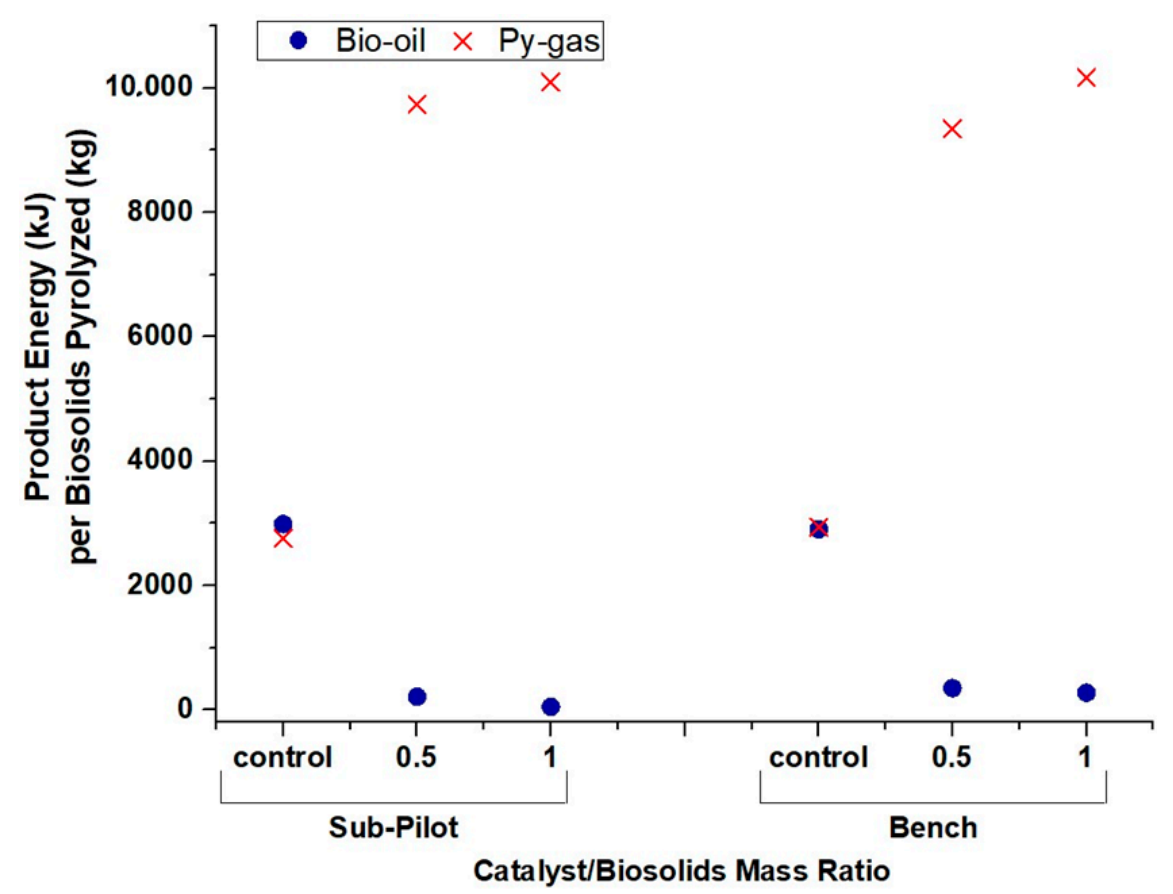

Figure 4. Py-gas and bio-oil energy yields ("control" denotes the $800{ }^{\circ} \mathrm{C}$ non-catalytic test with the downstream temperature of $500{ }^{\circ} \mathrm{C} ;$ " $0.5^{\prime \prime}$ and " 1 " indicate the $800{ }^{\circ} \mathrm{C}$ downstream autocatalytic tests performed with a catalyst/biosolids mass ratio of 0.5 and 1 , respectively; the bench-scale results were from our previous study [23]).

An energy balance analysis was conducted using the bench-scale results in our previous study and revealed that the autocatalytic process was endothermic at $800{ }^{\circ} \mathrm{C}$ [24]. Since the product energy per biosolids pyrolyzed during the sub-pilot-scale test was similar to that of the bench-scale, the sub-pilot-scale autocatalytic process could be endothermic as well. However, a fraction of the py-gas could be used to supply the heat for this endothermic process. A more detailed large-scale energy balance analysis is needed in the future.

\section{Materials and Methods}

\subsection{Materials}

Dried biosolids (Milorganite ${ }^{\circledR}$ ) were collected from the Jones Island water resource reclamation facility (Milwaukee, WI, USA). Milorganite ${ }^{\circledR}$ is a blend of waste activated sludge and anaerobically digested primary solids. Milorganite ${ }^{\circledR}$ contains $66.6 \%$ volatile solids, $7.70 \%$ fixed carbon, and $25.7 \%$ ash ( $w \mathrm{t} \%$, dry basis). The elements of Milorganite ${ }^{\circledR}$ were analyzed using Vario Micro Cube (Elementar, Hanau, Germany) and X-ray fluorescence (XRF-1800, Shimadzu, Kyoto, Japan). The composition of major elements is listed in Table S1. Ethanol (95\% purity) was used for cleaning up the downstream units, including the condensing system by absorbing the remaining bio-oil on the inner wall surface. Ethanol was purchased from Sigma-Aldrich (Milwaukee, WI, USA). Argon was used as the inert gas during pyrolysis and the gas tank was obtained from Airgas Inc. (West Allis, WI, USA). 


\subsection{Methods}

\subsubsection{Sub-Pilot-Scale Pyrolytic System}

A sub-pilot-scale pyrolytic system (Figure 5) was used in this study to produce BBC and conduct autocatalytic tests. The system included a feeding system (feedstock silo, screw feeder), pyrolytic reactor with a large screw inside, biochar/bio-oil/py-gas collection systems (biochar discharge zone and collector, bio-oil collector, gas outlet), two heat exchangers, and control systems for both the temperature and the screw. In addition, the system was specifically equipped with a downstream cylindrical reactor, which can be used as a catalytic reactor when filled with catalyst. This system had a solid feeding capacity of $4 \mathrm{~kg} / \mathrm{h}(\sim 0.1$ ton/day). The system can be pressurized to $100 \mathrm{psi}$ and both pyrolytic and catalytic reactors can be heated up to $900{ }^{\circ} \mathrm{C}$.

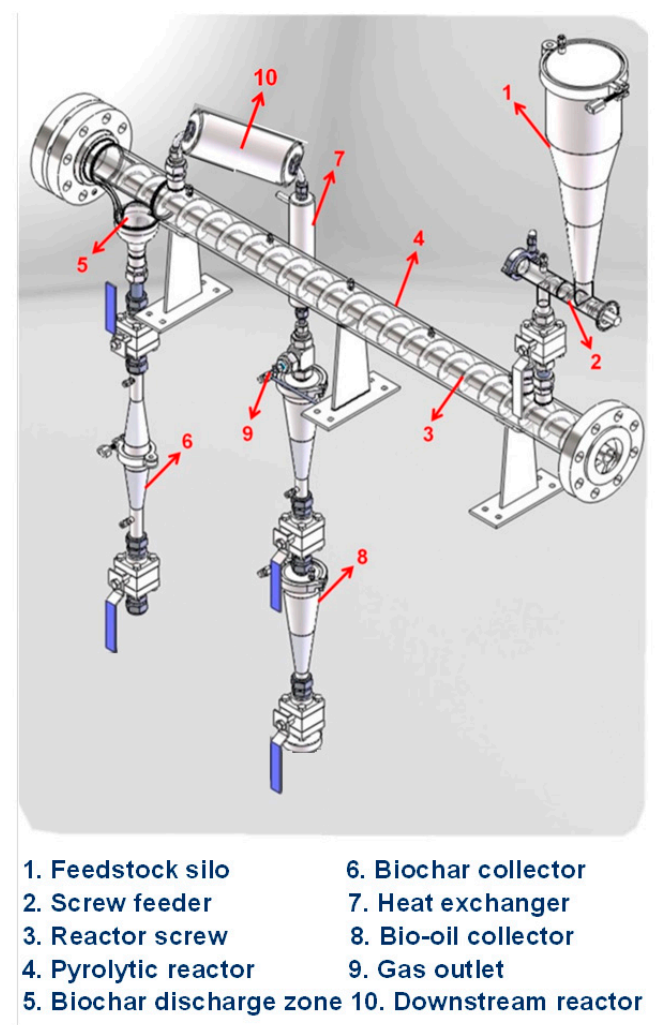

Figure 5. The rendering of the sub-pilot-scale pyrolytic system.

\subsubsection{Biosolids Non-Catalytic and Autocatalytic Pyrolysis}

During the pyrolysis test, the feedstock in the silo was fed into the hot pyrolysis reactor by a small screw. Then the feedstock was conveyed to the biochar discharge zone by the big screw in the reactor. The feedstock feeding rate and the pyrolysis residence time were controlled by the screw rotation speed. The residence time of all the tests were $20 \mathrm{~min}$. The pyrolysis vapor and the resulting biochar were separated in the discharge zone. The vapor went through the downstream reactor (with or without $\mathrm{BBC}$ depending on the test requirement) and the biochar dropped into the biochar collector. The py-gas and the bio-oil were separated in the condensing system, which has two high-capacity heat exchangers in tandem. A very small amount of uncondensed vapor was finally captured by a large activated carbon filter. A gas sampling point was located at the end of the system to collect the gas for a duration using a large Tedlar ${ }^{\circledR}$ bag. The remaining tail gas was extracted to the building roof by a ventilation system, including a powered draft fan. The bio-oil was collected in the two condensers. During each test, argon was used to flush the system resulting in an oxygen-deficient environment 
with a flow rate of $100 \mathrm{cc} / \mathrm{min}$. The picture of the sub-pilot-scale pyrolytic system with key units highlighted is shown in Figure S5.

For the non-catalytic pyrolysis tests, one was performed for system validation at $500{ }^{\circ} \mathrm{C}$ and the other was performed for control at $800{ }^{\circ} \mathrm{C}$ in comparison with the autocatalytic pyrolysis. For the validation test, the pyrolysis reactor was set at $500^{\circ} \mathrm{C}$ and the downstream reactor was $500^{\circ} \mathrm{C}$ without any BBC addition. The biosolids was fed into the system at a feeding rate of $0.7 \mathrm{~kg} / \mathrm{h}$ for an hour. For the control test, the pyrolysis reactor was set at $800{ }^{\circ} \mathrm{C}$ and the downstream reactor was $500{ }^{\circ} \mathrm{C}$ without any BBC addition. The biosolids was fed into the system at a feeding rate of $0.9 \mathrm{~kg} / \mathrm{h}$ for an hour. The downstream temperature of $500{ }^{\circ} \mathrm{C}$ was to minimize the condensation of pyrolysis vapor constituents during conveyance to the heat exchangers and to minimize the effect of secondary, homogeneous reactions among vapor components at high temperature [36,37].

For the autocatalytic pyrolysis tests, one scenario was in-situ catalysis and the other scenario was downstream catalysis. The BBC used in these tests was the original biochar made from the $800{ }^{\circ} \mathrm{C}$ control test without further modification or shaping. For in-situ catalysis, the pyrolysis reactor was set at $800^{\circ} \mathrm{C}$ and the downstream reactor was $500^{\circ} \mathrm{C}$ without any BBC addition. The BBC was fully premixed with biosolids in the feeding silo and the mass ratio of catalyst to biosolids was 1 . The biosolids/BBC mixture was fed into the system for an hour with a feeding rate of $0.5 \mathrm{~kg} / \mathrm{h}$. For downstream catalysis, the pyrolysis reactor was set at $800{ }^{\circ} \mathrm{C}$ and the downstream reactor was $800^{\circ} \mathrm{C}$ with the addition of $0.45 \mathrm{~kg}$ of BBC. Corresponding to two different catalyst to biosolids mass ratios of 1 and 0.5 , the biosolids feeding rate was controlled at $0.45 \mathrm{~kg} / \mathrm{h}$ and $0.9 \mathrm{~kg} / \mathrm{h}$, respectively. The biosolids was supplied to the system for an hour. The detailed experimental design of autocatalytic and non-catalytic testing is listed in Table 1. All experiments were performed in duplicate.

Table 1. Experimental design of autocatalytic and non-catalytic testing.

\begin{tabular}{|c|c|c|c|c|c|c|}
\hline & $\begin{array}{c}\text { Pyrolysis } \\
\text { Temperature }\left({ }^{\circ} \mathrm{C}\right)\end{array}$ & $\begin{array}{c}\text { Downstream } \\
\text { Temperature } \\
\left({ }^{\circ} \mathrm{C}\right)\end{array}$ & $\begin{array}{l}\text { Downstream Catalyst } \\
\text { Loading }(\mathbf{k g})\end{array}$ & $\begin{array}{c}\text { Feeding Rate } \\
(\mathrm{kg} / \mathrm{hr})\end{array}$ & $\begin{array}{c}\text { Feeding } \\
\text { Duration (min) }\end{array}$ & Comment \\
\hline \multirow{3}{*}{ Autocatalytic } & 800 & 800 & 0.45 & 0.45 & 60 & $\begin{array}{l}\text { downstream catalysis } \\
\text { with biosolids feeding } \\
\text { (catalyst/biosolids }=1 \text { ) }\end{array}$ \\
\hline & 800 & 800 & 0.45 & 0.9 & 60 & $\begin{array}{c}\text { downstream catalysis } \\
\text { with biosolids feeding } \\
\text { (catalyst/biosolids }=0.5 \text { ) }\end{array}$ \\
\hline & 800 & 500 & 0 & 0.5 & 60 & $\begin{array}{l}\text { in-situ catalysis with } \\
\text { biosolids / biochar } \\
\text { mixture feeding } \\
\text { (catalyst/biosolids = 1) }\end{array}$ \\
\hline \multirow{2}{*}{ Non-Catalytic } & 800 & 500 & 0 & 0.9 & 60 & control test \\
\hline & 500 & 500 & 0 & 0.7 & 60 & validation test \\
\hline
\end{tabular}

\subsubsection{Product Analyses}

The masses of biochar and bio-oil were measured gravimetrically. In particular, the majority of bio-oil was from the condensers ( $\sim 95 \mathrm{wt} \%)$. Some sticky bio-oil that was originally attached to the inner wall of all the downstream units was washed out using ethanol. The weight difference between ethanol input and eluent output was bio-oil mass from the inner wall. In addition, the mass of the bio-oil that was captured by the activated carbon filter was obtained based on the filter weight difference before and after each test. Hence, the bio-oil total mass included the condenser bio-oil mass, inner wall bio-oil mass, and filter bio-oil mass. The py-gas mass was calculated by difference (i.e., biosolids feeding mass minus the sum of biochar and bio-oil).

Py-gas composition $\left(\mathrm{H}_{2}, \mathrm{CH}_{4}, \mathrm{CO}\right.$, and $\mathrm{CO}_{2}$ concentrations) was determined by GC (Agilent Technologies 7890A, Santa Clara, CA, USA) with a thermal conductivity detector as described elsewhere [16,17]. Chemical constituents in the bio-oil were characterized by GC-MS (7890B coupled with 5977A, Agilent Technologies, Santa Clara, CA, USA) for qualitative analysis at Iowa State University's Bioeconomy Institute as described by Brown et al. (2015) [38]. 
The HHV of py-gas was calculated based on each component concentration and corresponding HHV. The HHVs of bio-oil and biochar were determined using bomb calorimetry (Parr 1341, Parr Instrument Company, Moline, IL, USA). The product energy per mass of biosolids pyrolyzed ( $\mathrm{kJ} / \mathrm{kg}$-biosolids) was calculated by multiplying each pyrolysis product yield with its corresponding HHV (e.g., py-gas yield multiplied by py-gas HHV).

\section{Conclusions and Prospective}

This study demonstrated that autocatalytic pyrolysis of biosolids can be feasible on a large scale. The sub-pilot-scale test with the downstream catalysis had better catalytic performance with higher py-gas yield and lower bio-oil yield in comparison with the previous bench-scale results. The in-situ catalysis process showed the potential to increase py-gas yield, but the increase was limited. It was expected that using a higher input pyrolyzer with a better mixing condition would further improve the in-situ autocatalytic performance in terms of the py-gas yield. Overall, using biosolids biochar as a catalyst for biosolids pyrolysis can increase the py-gas yield and energy.

Py-gas is relatively clean for convenient energy recovery when compared to bio-oil, which requires further conditioning (in particular, many WRRFs already produce and combust anaerobic digester biogas for on-site energy recovery; it is most likely to co-combust biogas and py-gas using existing boilers or engines to generate more energy for on-site use). Moreover, biosolids biochar proved to be an efficient adsorbent for contaminant removal and a good soil amendment for plant growth [39-41]. The biosolids derived bio-oil can also be co-digested anaerobically to produce more renewable fuel (i.e., biogas) via specific pretreatment or using acclimated biomass [42]. Therefore, the autocatalytic pyrolysis process can be coupled with other existing technologies and applications to simultaneously enhance energy recovery, minimize adverse environmental impacts, and generate value-added products from wastewater $[43,44]$.

\section{Patents}

Daniel Zitomer, Zhongzhe Liu, Patrick McNamara, Catalysts for pyrolysis. (No. PCT/US2017/038130).

Supplementary Materials: The following are available online at http:/ /www.mdpi.com/2073-4344/8/11/524/s1, Figure S1: Process diagram of the autocatalytic pyrolysis of biosolids, Figure S2: Product yields and optical properties of the sub-pilot-scale test and the bench-scale test $\left(500{ }^{\circ} \mathrm{C}\right)$, Figure S3: Bio-oil optical property from the sub-pilot-scale tests, Figure S4: Bio-oil and py-gas energy contents, Figure S5: The picture of the sub-pilot-scale pyrolytic system with key units highlighted, Table S1: Elemental analysis of Milorganite ${ }^{\circledR}$.

Author Contributions: Conceptualization, P.M., Z.L. and S.S.; methodology, Z.L.; formal analysis, Z.L.; investigation, Z.L.; data curation, Z.L.; writing—original draft preparation, Z.L.; writing—review and editing, P.M., D.Z. and S.S.; supervision, P.M.; project administration, P.M.; funding acquisition, P.M., Z.L., S.S. and D.Z.

Funding: This large-scale research was funded by MMSD Research Grants M03029P16 and M03029P36, Water Quality Center at Marquette University, and Marquette University.

Acknowledgments: We are thankful for the mentorship provided throughout the project by Matthew Magruder from MMSD. Laboratory assistance from Zachary Pederson, Matthew Hughes, and Erik Anderson is greatly appreciated. We are also grateful to Robert Brown and Patrick Johnston of the Iowa State University Bioeconomy Institute for providing bio-oil GC-MS analysis.

Conflicts of Interest: The authors declare no conflict of interest. The funders had no role in the design of the study; in the collection, analyses, or interpretation of data; in the writing of the manuscript. MMSD reviewed the manuscript prior to submission to ensure that there was no release of confidential information.

\section{References}

1. Jhansi, S.C.; Mishra, S.K. Wastewater Treatment and Reuse: Sustainability Options. Cons. J. Sustain. Dev. 2013, 10, 1-15.

2. Eggen, R.I.L.; Hollender, J.; Joss, A.; Schärer, M.; Stamm, C. Reducing the discharge of micropollutants in the aquatic environment: The benefits of upgrading wastewater treatment plants. Environ. Sci. Technol. 2014, 48, 7683-7689. [CrossRef] [PubMed] 
3. Venkatesan, A.K.; Hamdan, A.-H.M.; Chavez, V.M.; Brown, J.D.; Halden, R.U. Mass Balance Model for Sustainable Phosphorus Recovery in a US Wastewater Treatment Plant. J. Environ. Qual. 2016, 45, 84-89. [CrossRef] [PubMed]

4. Mo, W.; Zhang, Q. Energy-nutrients-water nexus: Integrated resource recovery in municipal wastewater treatment plants. J. Environ. Manag. 2013, 127, 255-267. [CrossRef] [PubMed]

5. Gude, V. Energy positive wastewater treatment and sludge management. Edorium J. Waste Manag. 2015, 1, $10-15$.

6. Cao, Y.; Pawłowski, A. Sewage sludge-to-energy approaches based on anaerobic digestion and pyrolysis: Brief overview and energy efficiency assessment. Renew. Sustain. Energy Rev. 2012, 16, 1657-1665. [CrossRef]

7. Xia, K.; Hundal, L.; Kumar, K. Triclocarban, triclosan, polybrominated diphenyl ethers, and 4-nonylphenol in biosolids and in soil receiving 33-year biosolids application. Environ Toxicol Chem. 2010, 29, 597-605. [CrossRef] [PubMed]

8. Bright, D.A.; Healey, N. Contaminant risks from biosolids land application. Environ. Pollut. 2003, 126, 39-49. [CrossRef]

9. Singh, R.P.; Agrawal, M. Potential benefits and risks of land application of sewage sludge. Waste Manag. 2008, 28, 347-358. [CrossRef] [PubMed]

10. Carey, D.E.; Zitomer, D.H.; Hristova, K.R.; Kappell, A.D.; McNamara, P.J. Triclocarban Influences Antibiotic Resistance and Alters Anaerobic Digester Microbial Community Structure. Environ. Sci. Technol. 2016, 50, 126-134. [CrossRef] [PubMed]

11. Carey, D.; Zitomer, D.H.; Kappell, A.; Choi, M.; Hristova, K.; McNamara, P. Chronic exposure to triclosan sustains microbial community shifts and alters antibiotic resistance gene levels in anaerobic digesters. Environ. Sci. Process. Impacts 2016. [CrossRef] [PubMed]

12. Rulkens, W. Sewage sludge as a biomass resource for the production of energy: Overview and assessment of the various options. Energy Fuels 2008, 22, 9-15. [CrossRef]

13. Chen, D.; Yu, Y.; Zhu, H.; Liu, Z.; Xu, Y. Ferrite process of electroplating sludge and enrichment of copper by hydrothermal reaction. Sep. Purif. Technol. 2008, 62, 297-303. [CrossRef]

14. Lumley, N.P.G.; Ramey, D.F.; Prieto, A.L.; Braun, R.J.; Cath, T.Y.; Porter, J.M. Techno-economic analysis of wastewater sludge gasification: A decentralized urban perspective. Bioresour. Technol. 2014, 161, 385-394. [CrossRef] [PubMed]

15. Bridle, T.; Pritchard, D. Energy and nutrient recovery from sewage sludge via pyrolysis. Water Sci. Technol. 2004, 50, 169-175. [CrossRef] [PubMed]

16. McNamara, P.; Koch, J.; Zitomer, D. Pyrolysis of Wastewater Biosolids: Lab-Scale Experiments and Modeling. Proc. Water Environ. Fed. 2014, 2014, 1-14. [CrossRef]

17. McNamara, P.J.; Koch, J.D.; Liu, Z.; Zitomer, D.H. Pyrolysis of Dried Wastewater Biosolids Can Be Energy Positive. Water Environ. Res. 2016, 88, 804-810. [CrossRef] [PubMed]

18. Samolada, M.C.; Zabaniotou, A.A. Comparative assessment of municipal sewage sludge incineration, gasification and pyrolysis for a sustainable sludge-to-energy management in Greece. Waste Manag. 2014, 34, 411-420. [CrossRef] [PubMed]

19. Ross, J.J.; Zitomer, D.H.; Miller, T.R.; Weirich, C.A.; McNamara, P.J. Emerging investigators series: Pyrolysis removes common microconstituents triclocarban, triclosan, and nonylphenol from biosolids. Environ. Sci. Water Res. Technol. 2016, 2, 282-289. [CrossRef]

20. Hoffman, T.C.; Zitomer, D.H.; McNamara, P.J. Pyrolysis of Wastewater Biosolids Significantly Reduces Estrogenicity. J. Hazard. Mater. 2016. [CrossRef] [PubMed]

21. Kimbell, L.K.; Kappell, A.D.; McNamara, P.J. Effect of pyrolysis on the removal of antibiotic resistance genes and class I integrons from municipal wastewater biosolids. Environ. Sci. Water Res. Technol. 2018. [CrossRef]

22. Sadaka, S.; Boateng, A. Pyrolysis and Bio-Oil; University of Arkansas System: Little Rock, AR, USA, 2009.

23. Liu, Z.; McNamara, P.; Zitomer, D. Autocatalytic Pyrolysis of Wastewater Biosolids for Product Upgrading. Environ. Sci. Technol. 2017, 51, 9808-9816. [CrossRef] [PubMed]

24. Liu, Z.; Singer, S.; Zitomer, D.; McNamara, P. Can Autocatalytic Pyrolysis of Wastewater Biosolids be Energy Neutral and Generate Value-Added Products? Proc. Water Environ. Fed. 2017, 2017, 360-364. [CrossRef]

25. Liu, Z.; McNamara, P.; Zitomer, D. Product Upgrading during Biosolids Pyrolysis by Using a Low-cost Natural Catalyst. Proc. Water Environ. Fed. 2016, 796-802. [CrossRef] 
26. Chang, F.; Wang, C.; Wang, Q.; Jia, J.; Wang, K. Pilot-scale pyrolysis experiment of municipal sludge and operational effectiveness evaluation. Energy Sources Part A Recover. Util. Environ. Eff. 2016, 38, $472-477$. [CrossRef]

27. Lin, Q.H.; Cheng, H.; Chen, G.Y. Preparation and characterization of carbonaceous adsorbents from sewage sludge using a pilot-scale microwave heating equipment. J. Anal. Appl. Pyrolysis 2012, 93, 113-119. [CrossRef]

28. Lin, Q.; Chen, G.; Liu, Y. Scale-up of microwave heating process for the production of bio-oil from sewage sludge. J. Anal. Appl. Pyrolysis 2012, 94, 114-119. [CrossRef]

29. Sánchez, M.E.; Martínez, O.; Gómez, X.; Morán, A. Pyrolysis of mixtures of sewage sludge and manure: A comparison of the results obtained in the laboratory (semi-pilot) and in a pilot plant. Waste Manag. 2007, 27, 1328-1334. [CrossRef] [PubMed]

30. Dayton, D.C.; Carpenter, J.R.; Kataria, A.; Peters, J.E.; Barbee, D.; Mante, O.D.; Gupta, R. Design and operation of a pilot-scale catalytic biomass pyrolysis unit. Green Chem. 2015, 17, 4680-4689. [CrossRef]

31. Mendes, F.L.; Ximenes, V.L.; de Almeida, M.B.B.; Azevedo, D.A.; Tessarolo, N.S.; de Rezende Pinho, A. Catalytic pyrolysis of sugarcane bagasse and pinewood in a pilot scale unit. J. Anal. Appl. Pyrolysis 2016, 122, 395-404. [CrossRef]

32. Domínguez, A.; Fernández, Y.; Fidalgo, B.; Pis, J.J.; Menéndez, J.A. Biogas to Syngas by Microwave-Assisted Dry Reforming in the Presence of Char. Energy Fuels 2007, 21, 2066-2071. [CrossRef]

33. Muradov, N.; Fidalgo, B.; Gujar, A.C.; Garceau, N.; T-Raissi, A. Production and characterization of Lemna minor bio-char and its catalytic application for biogas reforming. Biomass Bioenergy 2012, 42, 123-131. [CrossRef]

34. Sappok, M.; Wagels, D. Method for Stabilizing Heating Oil or Diesel Oil, Particularly Heating Oil or Diesel Oil from the Depolymerization of Hydrocarbon-Containing Residues, or Pyrolysis Oil. U.S. Patent No. 8,394,264, 12 March 2013.

35. Ren, S.; Lei, H.; Wang, L.; Bu, Q.; Chen, S.; Wu, J. Hydrocarbon and hydrogen-rich syngas production by biomass catalytic pyrolysis and bio-oil upgrading over biochar catalysts. RSC Adv. 2014, 4, 10731-10737. [CrossRef]

36. Sun, Q.; Yu, S.; Wang, F.; Wang, J. Decomposition and gasification of pyrolysis volatiles from pine wood through a bed of hot char. Fuel 2011, 90, 1041-1048. [CrossRef]

37. Gilbert, P.; Ryu, C.; Sharifi, V.; Swithenbank, J. Tar reduction in pyrolysis vapours from biomass over a hot char bed. Bioresour. Technol. 2009, 100, 6045-6051. [CrossRef] [PubMed]

38. Rover, M.; Hall, P.; Johnston, P.; Smith, R.; Brown, R. Stabilization of bio-oils using low temperature, low pressure hydrogenation. Fuel 2015, 153, 224-230. [CrossRef]

39. Tong, Y.; Mayer, B.K.; McNamara, P.J. Triclosan adsorption using wastewater biosolids-derived biochar. Environ. Sci. Water Res. Technol. 2016, 2, 761-768. [CrossRef]

40. Kimbell, L.K.; Tong, Y.; Mayer, B.K.; McNamara, P.J. Biosolids-Derived Biochar for Triclosan Removal from Wastewater. Environ. Eng. Sci. 2017, 35, ees.2017.0291. [CrossRef]

41. Carey, D.E.; McNamara, P.J.; Zitomer, D.H. Biochar from Pyrolysis of Biosolids for Nutrient Adsorption and Turfgrass Cultivation. Water Environ. Res. 2015, 87, 2098-2106. [CrossRef] [PubMed]

42. Seyedi, S. Anaerobic Co-digestion of Aqueous Liquid from Biosolids Pyrolysis. Master's Thesis, Marquette University, Milwaukee, WI, USA, 2018.

43. Liu, Z.; Singer, S.; Tong, Y.; Kimbell, L.; Anderson, E.; Hughes, M.; Zitomer, D.; McNamara, P. Characteristics and applications of biochars derived from wastewater solids. Renew. Sustain. Energy Rev. 2018, 90, 650-664. [CrossRef]

44. Liu, Z.; Zitomer, D.; McNamara, P.; Mayer, B.; Parolari, A.; McDonald, W. NEWAGE: A system with enhanced energy recovery and value-added products from wastewater and wastewater biosolids for agriculture and green. In Abstracts of Papers of the American Chemical Society; American Chemical Society: Washington, DC, USA, 2017; Volume 254, ISBN 1155 16TH ST.

(C) 2018 by the authors. Licensee MDPI, Basel, Switzerland. This article is an open access article distributed under the terms and conditions of the Creative Commons Attribution (CC BY) license (http:/ / creativecommons.org/licenses/by/4.0/). 